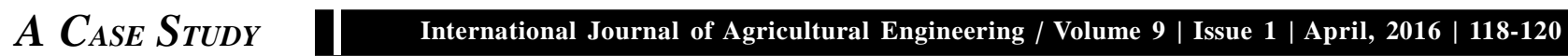
$\Rightarrow$ e ISSN-0976-7223 $\square$ Visit us : www.researchjournal.co.in $\square$ DOI: 10.15740/HAS/IJAE/9.1/118-120

\title{
Development of improved intercultural hoe
}

\section{B. CHITTAPPA, R. NISHA AND C. NICKHIL}

Received : 22.01.2016; Accepted : 30.03 .2016

See end of the Paper for authors' affiliation

Correspondence to :

\section{B. CHITTAPPA}

Department of Agricultural Engineering, College of Agriculture, BENGALURU (KARNATAKA) INDIA
-ABSTRACT : The interculturing operation breaks the upper surface of the soil, uprooting the weeds, aerating the soil, making good mulch, so moisture inside properly retained from evaporation. In the animal-drawn hoe, the implement draft and the capacity of the animals to provide the required power will also affect performance, as will ergonomic considerations related to the comfort of the operator. A intercultural hoe could be easily handled, light, strong, durable, cheap, adjustable for different crops and can be easily manufactured locally. The present bullock hoe consists occupied the space coverage of width $95 \mathrm{~cm}$, total height of $102 \mathrm{~cm}$, three number of tynes and angle $41^{\circ}$. The shape of blade is rectangular and beam length of $236 \mathrm{~cm}$. The field capacity of the implement was noted to be 0.27 hectares per hour which included the turning losses, the field capacity was found to be 0.17 hectares per hour for the area of $10 \times 20 \mathrm{~m}^{2}$, which gives the field efficiency of 81.43 per cent.

- KEY WORDS : Field, Implement, Hoe, Bullock, Blade

- HOW TO CITE THIS PAPER : Chittappa, B., Nisha, R. and Nickhil, C. (2016). Development of improved intercultural hoe. Internat. J. Agric. Engg., 9(1) : 118-120. 